\title{
Events of August '91 as an Expression of Political Disobedience in the Process of Shaping Civil Conduct
}

\begin{abstract}
Civil disobedience is the attitude which in the 20th century proved to be the only effective form of resistance to authoritarian regimes. So it was in the case of the events of August '91 when the Soviet society objected to the activities of the State Committee on the State of Emergency. It would not have been possible without the reform programme known as perestroika initiated by the last USSR leader Mikhail Gorbachev. Thanks to perestroika and the accompanying glasnost - transparency of socio-political life - the previously apathetic and alienated Soviet society felt responsible for their own life and for the fate of the State. By opposing the rebels through passive resistance, the citizens proved to the leaders of their own country, to the world, and above all, to themselves that they were aware of their rights and responsibilities. The process of socio-political socialization stimulated the development of civil society in the Soviet Union.
\end{abstract}

\section{Keywords:}

Yanayev putsch, coup d'état, civil disobedience, USSR, Russia, civil society, perestroika

1 Institute of Russian and East European Studies, Jagiellonian University in Kraków, Poland, anna.jach@uj.edu.pl. 
In today's world citizens of every country are provided with a range of means that can be used to express opinions on their state as well as on the role of its society or an individual themselves. This is referred to as a state of consciousness shared by a given collective reacting to political and social actions which takes a form of an openly expressed attitude to surrounding reality. Public opinion, shaped during the ongoing process of socio-political socialization, wields influence on citizens' choices of measures used both to present their views and to achieve the previously set goals.

One of such measures is the phenomenon called „civil disobedience”. It is employed in order to publicly articulate an opinion usually different from, firstly, the officially binding legal regulations and secondly, from the everyday practice. Citizens resorting to civil disobedience intentionally take actions which contravene particular legal articles since they believe these articles infringe their core values. Firstly, practitioners of civil disobedience are fully aware of the possibility of having to face the legal consequences of their actions. Secondly, accepting these consequences is treated by them as another means of expressing their dissent. Thirdly, citizens understand civil disobedience as nonviolent resistance whose aim is to change or uphold particular types of social behaviour (Hergren, 1997, p. 9).

Political disobedience as a phenomenon had not been described until the 19th century although the practice of expressing public opinion had been known since the antiquity and existed in all states ${ }^{2}$.

The subject of this analysis is the phenomenon of political civil disobedience which was present in the declining years of the Soviet Union. This topic is of considerable significance, especially when we consider the specificity of Russian political system and the political regime established at the turn of the 20th and 21st centuries which resulted from those events.

The first evidence of mass „civil disobedience” at the end of the 20th century which had its far-reaching consequences not only for Russian citizens but also for the whole world was the coup d'état which took place in Moscow in August 1991.

2 The first one who described and called for civil disobedience was Henry David Thoreau. In the essay, published in 1849, Civil Disobedience, he encouraged people not to pay taxes in order to express their disapproval of the war against Mexico and of slavery in America. Thoreau himself refused to pay the due taxes and, fully aware, he accepted a prison sentence. Thoreau's behaviour and his views published in Civil Disobedience became the basis of this particular way of expressing opposition to the law or to any adopted resolutions. (Thoreau, 1997) Among other works of fundamental value for the analysis of social activities in the context of civil disobedience, it is necessary to mention e.g. A Theory of Justice by John Rawls (Rawls, 1994), On Violence. Civil Disobedience. by Hannah Arendt (Arendt, 1998), or the classic essay From Dictatorship to Democracy, A Conceptual Framework for Liberation by Gene Sharp (Sharp, 2013). 
The coup, referred to as the August Putsch, was plotted by the closest collaborators of the first and the last (as it later transpired) President of the Soviet Union, Mikhail Gorbachev. The aim of the rebels was to prevent the dissolution of the union state by using the well-known and previously effective methods of „restoring order”.

Among those who adopted such a radical solution were the head of the KGB USSR Vladimir Kryuchkov, the Minister of Defence of the Soviet Union Marshal Dmitry Yazov, the Minister of Internal Affairs Boris Pugo, the Vice President of the Soviet Union Gennady Yanayev, and the Chairman of the Supreme Soviet of the Soviet Union Anatoly Lukyanov. On 18 August 1991, they formed the State Committee on the State of Emergency (GKChP), which acting in an autocratic manner on behalf of the Soviet nation, introduced the state of emergency on the USSR territory. This move was to be justified by an alleged illness of the head of the state preventing him from holding the office and by the progressive territorial disintegration led by internal enemies. In order to sustain territorial integrity, the authority over the state was given to the Vice President of the Soviet Union Gennady Yanayev, the supremacy of union law over republican law was restored, and, as it was mentioned earlier, the state of emergency was introduced for six months (Заявление, 1991; Обращение, 1991).

The intended course of action was to seize power from ineffectual, indecisive Gorbachev and to confer it to a group which was ideologically and organizationally prepared for this task. It was a classic, well-known in the past palace revolution which aimed at quiet, bloodless reshuffling on the central authority level. The rebels' belief in the rightness of their actions, excessive self-confidence and ignorance of the realities of life were shortly verified by the subsequent events. The putsch members smarted from that experience.

When we consider an intentional civil action, which assumes deliberate violation of the existing law and readiness to face legal consequences of this deed, we can undoubtedly conclude that the events which occurred during the 63-hour coup meet the criteria of civil disobedience. The type of behaviour, which is discussed here was displayed by at least three central figures of those events, two of which were the President of the Soviet Union Mikhail Gorbachev and the President of the Russian Soviet Federative Socialist Republic (RSFSR) Boris Yeltsin. The third figure, whose role was of the greatest importance during the August Coup, was a collective actor - the residents of Moscow. It was their courage and determination to achieve the set goal which became a foundation stone for building new civic awareness in Russian society.

Gorbachev was a typical communist apparatchik who was climbing up the career ladder in politics thanks to his dedication to the communist party and to 
the support of Yuri Andropov. Unlike his predecessors who held the office of the general secretary, Gorbachev distinguished himself by his young age, education, refinement, ability to speak in public, direct contact with people and commitment to Lenin's doctrine. He came to Moscow thanks to Andropov and soon became a member of his closest circle. In this way, he was naturally prepared by Andropov to become his successor. Gorbachev openly claimed that he was not a supporter of democratization, but he understood the need for reforms which would pull the state out of a crisis and reestablish its position of superpower on the international arena.

Eventually, in 1985, after two consecutive deaths of the secretaries of the CPSU (Andropov and Chernenko), Gorbachev was elected the leader of the Soviet Union and initiated the period of thorough reforms focusing mainly on the socioeconomic aspect, which was recognised by the Western states - the new gensek ${ }^{3}$ was perceived by the West as a true democrat. The policy changes introduced by Gorbachev had an impact also on Soviet citizens, whose consciousness and mentality underwent irreversible changes. Abandoning the previously used methods of repression resulted in a major revival in the society, which began to get involved in the socio-political and economic life of the state. Abolishing censorship, liberalization of law, rehabilitation of victims of the communist system, debunking the official history, broadcasts of authority meetings in the mass media, and finally, the increasingly critical attitude towards the communist party triggered in people the latent sense of participation and co-responsibility for the state. Obviously, that process did not touch all the citizens of the USSR, but only those most active particularly, the inhabitants of the Baltic states, the main USSR cities (Leningrad and Moscow), Ukraine and Belarus. The movement was also present, although not to such an extent, in the capitals of other union republics which more than once informed the central authorities about their stand.

When initiating perestroika in 1985, Mikhail Gorbachev did not realize - because he could not - its consequences for the state and for himself. He propagated the idea of returning to the original concept of Lenin's work and believed that by following Lenin's way towards democracy, he would repair the system. Gorbachev quoted Lenin who claimed that restructuring, openness of activities and democracy were essential. Of course, Ulyanov understood those words and their practical application in a completely different way. Gorbachev did not see it, or did not want to. Nevertheless, by promoting „перестройка”, „гласность” and „новое мышление” he changed the citizens' way of thinking as well as the way they

3 The colloquial name of the CPSU general secretary (abbreviation for Russian: генеральный секретарь). 
perceived themselves and the state in which they lived. As a consequence, they stopped being afraid.

In order to analyse the behaviour of the two individual political actors , Gorbachev and Yeltsin, it is necessary to take into account the above-mentioned circumstances and the personalities of the politicians themselves. Gorbachev, through his conscious refusal to submit to the introduced law and to the newly appointed Soviet governing body GKChP, displayed behaviour which can be acknowledged as an example of civil disobedience. He would not resort to the policy of repressions against political opponents or to strong-arm tactics in governing. However, the putsch members expected from him exactly the opposite. At the time of arriving in Foros, where the president was spending holidays with his family, the rebels did not expect that he would refuse cooperation so firmly. However, faithful to his ideals, Gorbachev did not agree to the demands of GKChP and threatened, during the conversation, to commit suicide. President Gorbachev's behaviour took the wind out of the sails of the „Soviet government” members. Thus before they managed to take any actions, they lost all their momentum.

Of course, there is also another interpretation of the events in Crimea, which suggests that Gorbachev not only did not refuse cooperation, but he adopted favourable attitude towards the GKChP members, and later he just „washed his hands” expecting that the „dirty work” would be done by the Committee. Such a version of events was presented by Gorbachev's foreign policy advisor Anatoly Chernyaev (Graczow, 2003, p. 373).

Later there emerged yet another version of the course of the August events. According to it, Gorbachev himself organized the coup d'état - a self-coup - in order to eliminate his opponents who were standing in his way to assume unlimited power - both the party hardliners and the leaders of the Union Republics whose interests were represented mainly by Boris Yeltsin (Sensacje XX wieku) ${ }^{4}$.

Although there have been a lot of controversy over how much the last (as it later turned out) president of the USSR knew and to what degree he was involved in the activities of the so called Soviet government, it is beyond doubt that the negative attitude which he expressed in Foros towards the plotters weakened

4 The version about self-coup is sustained by Bogusław Wołoszański who analyses the course of the coup in a documentary programme Sensacje XX wieku - Pucz Janajewa (Sensacje XX wieku, 1998). A similar opinion was included in the work on the history of power in the Soviet Union by Rudolf G. Pikhoia. The historian refers to the opinion of British journalists who (when assessing the August coup just after its end and the role which Gorbachev might have played in it) suggested the possibility that the whole strange coup was an element of a well-thought-out play in the political theatre, whose author could have been Gorbachev himself (Pichoja, 2011, p. 673). 
their will to act. Nevertheless, as a state leader and politician he was bearing full responsibility for the coup attempt. If it had not been for the firm attitude of the president of the Russian Republic and above all, of the Muscovites, who became the real heroes of those events, there would have been no peaceful dissolution of the Soviet Union. A crucial role in the process of the so called divorce with the USSR was played by Gorbachev, who by using slogans of democratic way of changes was striving for the most peaceful outcome. Certainly, he did not expect that the state which he had been leading for 6 years would collapse, but since he lacked strong character and willpower, unlike his political opponent Yeltsin, he allowed the first communist empire to gradually pass into oblivion. Of course, we must remember that in fact, he could not stop that process not only because of his indecisive personality, but mainly due to the growing desire for independence visible in the republics, the economic crisis choking the state and also, the domestic chaos reigning in the country.

The second example of civil disobedience was the activity of the president of the Russian Republic, which was a direct result of the rebels' neglect. Refusal to carry out orders by a part of military forces (e.g. the special purpose unit KGB USSR Alpha Group) and leaving Yeltsin free showed that the putsch members had a complete lack of insight into the internal situation of the state. The a priori assumption that the actions taken by GKChP would have a similar character to those of the 1964 coup, when Nikita Khrushchev was deprived of power, were preposterous. Similarly, looking for analogies between the communist authorities' operations undertaken in Poland 10 years earlier and the Soviet reality of 1991 did not have any application. When preparing the plan of removing Gorbachev from power and establishing strong-arm government, Kryuchkov did not take into account that as a result of the six years of perestroika the Soviet society was no longer the common voiceless ruck afraid of everything. Yeltsin became for those people a symbol of resistance and hope for better future, which led to the August revolution. At that significant moment, everyone could participate in the defence of the White House (the building used by the Supreme Soviet of Russia), the symbol of democracy.

Yeltsin was a brilliant speaker and with his message he could reach people's minds. His confidence and determination resulted in the growth of respect towards him as a defender not only of democracy in Russia, but also of the Soviet constitution, legal order and president Gorbachev himself. Previously known for his strong criticism of Gorbachev's government (procrastination in implementing reforms, indecisiveness, irresoluteness of character and aspirations for dictatorship), now when he came to the defence of the incumbent head of state, he immediately 
became an example to follow. Having realized that Yeltsin was sticking his neck out to defend the shared values, the citizens followed him and placed their trust in him.

Yeltsin's conduct during the 63-hour putsch was a testimonial for the effectiveness of civil disobedience. Similar behaviour was displayed by other members of socio-political life, who publicly expressed their stand. For instance, a Russian cellist and conductor Mstislav Rostropovich who, despite his advanced age, stood guard with a gun taken from another defender of the White House and therefore became the next visible and recognizable symbol of civil resistance. Another public person who supported Yeltsin was the former USSR Minister of Foreign Affairs Eduard Shevardnadze, who warned against the threat of dictatorship in the state as early as in 1990. The reaction of Muscovites gathered in front of the White House, seeing Shevardnadze standing at Yeltsin's side, confirmed their support for the defenders of constitutional order and for the state's authorities including Gorbachev, who remained in custody at that time. (Żegnajcie towarzysze, 2011).

Actions taken by the figures mentioned above, should be treated as acts of symbolic opposition and disobedience, which undermined moral and political control of the regime, in other words its legality. This, in turn, resulted in publicly expressed disapproval of GKChP and also of the whole communist system. The characteristic feature of the August events, which turned out to act as a catalyst for the subsequent events, was the fact that neither the communist party nor the Soviet state were defended by any structure, any group of citizens, any politician. Thus, thanks to the moral disapproval of the actions of the Soviet government, which was publicly expressed by the defenders of the White House, the coup ended in a resounding defeat for the putsch members.

If we take into account the aforementioned events, how should be the conduct of the Moscow residents assessed? Those citizens, as a collective political actor, expressed their opposition towards the rebels in a decisive, but not aggressive manner. Having realised that they could not be subject to any sanctions imposed by non-governmental structures, they showed their disapproval of using violence and took to the streets in order to bear testimony to the new social conduct. That seems to be the most important event preceding the birth of modern Russian society. Overcoming mental barriers and fears present in the society would not have been possible without Gorbachev's perestroika on one hand, and the leader - Boris Yeltsin, on the other. For the first time, the residents of the capital felt as owners of their city, as citizens of their own state.

The question about the reasons of such behaviour is difficult to answer. It is sufficient to look at the liberalization process of the communist system initiated in 1985 which took place in the economic (1985-1987), social (1986-1991), and 
political (1998-1991) spheres. Contrary to the CPSU general secretary's assumptions, the society was not burdened with responsibility for the condition of their state, but took active participation in its restructuring. Their deeper involvement was possible after Gorbachev:

- officially changed the style of governing the state, especially in the sphere of economy and foreign policy;

- resigned from the previously known practices of „restoring order and discipline"5;

- initiated the process of de-Stalinization, manifested through revealing the missing pages in Russian history and through rehabilitation of victims of Stalinist terror which was a part of a reform known as ,glasnost” (transparency in socio-political life);

- announced abolition of censorship;

- started the process of democratization of the political system.

All those changes resulted in irreversible transformation of the USSR citizens' mentality and in the birth of new political awareness.

Going back to the behaviour of Moscow citizens, it is necessary to underline that assuming the role of hosts of the city, they publicly expressed their dissatisfaction with the ongoing events, which was a task previously unknown on such scale. Breaking down the barrier of fear evoked in them a strong feeling of selfconfidence which did not lessen even in the face of threat of further repressions. That the citizens were demonstratively opposed to breaking the law caused mass social mobilization expressed in actions whose aim was to prevent an escalation of the situation which could lead to bloodshed.

It is worthwhile to underline here that both the defenders of the White House and the putsch members did not approve of violence during the coup ${ }^{6}$. In case of the rebels, the putsch members found their initially declared readiness to „spill a little blood in order to save the country from an even worse fate” (Dobbs, 1998, p. 392), impossible to accept and implement in reality. The death of three innocent residents

5 The supporter of such understood restructuring of the state was Yuri Andropov, the head of the KGB and the General Secretary of the CPSU in the years 1982-1984 (Thom, 1990, p.31).

6 The rebels' declarations of non-violent actions towards the citizens provoke serious reservations since those words were not supported by actions. The plan of launching the coup, prepared for the head of the KGB Kryuchkov, included interning the political opponents. Similarly, deploying troops on to the streets proved that they could be used for suppressing the signs of social discontent. However, the reality turned out to be totally different as the first fatalities showed the rebels' lack of readiness to take responsibility for the initiated actions (Graczow, p. 380). It is probably a fair assumption to say that the intended role of the military forces engaged by the putsch members was to intimidate the society, as it happened in Poland in 1981. 
of Moscow (Vladimir Usov, Ilya Krichevsky, Dmitry Komar) forced the rebels to stop their actions. As a result, the involvement of the citizens was mostly focused on preventing the relatively passive demonstration of military forces controlled by GKChP from turning into full-scale riots whose consequences would inflict heavy casualties on both sides.

The fear of civil war was so strongly present that it gave the citizens, who were aware of the threat, sleepless nights. Thus they summoned up their strength in order to develop such mechanisms of influence which would reduce or eliminate the threat. Among the means used by the residents of Moscow as a part of civil disobedience there were such natural ones as talks, discussions, speeches of wellknown representatives of culture and science as well as politics (Boris Yeltsin, Gavriil Popov), declarations from independent institutions (the Moscow Stock Exchange $^{7}$ (Boriew, 1992)) and organizations, and open letters giving full support for the defenders of democracy ${ }^{8}$.

Both the Soviet mass media and numerous representatives of the foreign press present in Moscow at that time backed up the actions of the citizens. The Muscovites gained advantage also due to grave mistakes made by the rebels who left the internal and external borders open and did not bring censorship into effect, which resulted in the full flow of information about the ongoing events between individual subjects and in comprehensive coverage received by foreign states. Moreover, the citizens themselves systematically registered the course of events either by recording them on VHS cassettes or by interviewing the witnesses and participants. Later, those materials were used to create the chronicle of August '91 Пучь. Хроника тревожних дней - Москва 1991 (Пучь, 1991a) or the chronicle by Vladimir Borev (Boriew, 1992).

Using the typology of peaceful resistance provided by Gene Sharp (2013, pp. 98-107), among the methods found in the canon of civil disobedience and adopted by the Soviet citizens we can find:

I. Formal statements - the initiative passed into the hands of the RSFSR president Boris Yeltsin, who by appealing to the residents of Moscow to civil disobedience

7 The engagement of the state institutions, such as the Moscow Stock Exchange, was discussed in Borev's chronicle (Boriew, 1992).

8 The August putsch is described in the chronicle written by the members of those events Путч. Хроника тревожних дней - Москва 1991. Retrieved from: http://old.russ.ru/antolog/1991/index. html (Путч, 1991 a) and Обухов С.П., (2005). Российский парламентаризм между признанием а отторжением. Проблема массого восприяния (1985-2005 гг.), Москва: ИПЦ «Маска». (Обухов, С.П., 2005). 
seized the initiative in the capital and, in consequence, formed under his leadership a counterbalance to the rebels:

1. Public speeches - during the 63-hour coup d'état, in different parts of the city, there were numerous speeches in which well-known politicians (Yeltsin, Popov, Shevardnadze) and ordinary citizens called the gathered crowds to resistance but without recourse to violence. Similar speeches were delivered in other big cities of the Soviet Union - e.g. in Leningrad (Собчак, 1999, с. 216).

2. Declarations by organizations and institutions - the declarations were formulated by the Moscow Stock Exchange, whose employees in order to express their protest made a statement in which they criticized the coup. In token of their solidarity with the „democrats” and in response to the appeal of the Chairman of the Exchange Committee Yuri Milyukov all the stock exchanges in the country stopped working (Boriew, 1992, pp. 40-41).

3. Open letters, signed by influential groups - similar public support for the defenders of the White House was expressed by a circle of journalists. Borev (1992), as a journalist himself, refers to the pamphlet „On the Fifth Anniversary of Introducing the Curfew in Moscow" which alludes to the State Defense Committee created in 1941 by Stalin. In their conclusions, the journalists stated that the contemporary democrat is more terrifying than a German fascist by exactly 1 hour (1992, pp. 42-43).

II. Communications with a wider audience - despite imposing censorship and partially suspending the activity of some press organs on the strength of the Declaration of the Soviet Government, mass media worked without disruption. Both independent radio stations and TV channels ran special live broadcast of the events. The radio station „Echo of Moscow” stopped broadcasting for some time, but that was rather an incident during the August events which made the situation even more serious (Пинскер, 2000). Also the journalists themselves, both Soviet and foreign ones present in Russia at that time, were giving a detailed account of the events happening in the places where they were currently staying. We can mention here, for example, Vladimir Borev, Boris Reitschuster, Michael Dobbs or Krystyna Kurczab-Redlich. Due to their work and commitment, the USSR citizens as well as the whole world could follow the events of the Moscow putsch. Live broadcast on the events was also provided by BBC and CNN (Кречетников, 2006):

1. Slogans, caricatures, and symbols.

2. Banners, posters. 
3. Leaflets, brochures, publications.

4. Newspapers and journals.

5. Records, radio, and television.

\section{Symbolic public acts (displaying national symbols):}

1. Flying the Russian flag and national colours (Манифестация, 1991), flying the RSFSR flag with the cut out hammer and sickle emblem (Путч, 1991б).

2. Displaying portraits.

3. Painting graffiti to express protest.

IV. Pressures on individuals - the press conference organized on 19 August 1991 by the putsch members which became a subject of lavatory jokes among the citizens. During the conference, its organizers were unable to convince the gathered journalists and, first of all, the world leaders to accept their ideas:

1. Deriding functionaries and officials.

V. Drama and music - there were spontaneous concerts held on the streets of the capital; groups of Muscovites were singing patriotic songs. Those kinds of behaviour raised morale and influenced the state of mind both of the musicians and the society. One of the symbols of civil resistance was the previously mentioned outstanding Russian conductor and cellist Mstislav Rostropovich, who despite his advanced age, took a gun and stood on the barricades in order to defend the White House (Радио «Эхо Москвы», 1991):

1. Concerts.

2. Spontaneous singing.

VI. Honouring the dead - three young people - Vladimir Usov, Ilya Krichevsky, Dmitry Komar - died during the coup and their funerals turned into socio-political demonstrations. The deceased were commemorated in films, in songs and on postage stamps (Pichoja, 2011, p. 673):

1. Demonstrations during the funerals of the three casualties.

2. Paying homage at the place of death.

\section{Public assemblies:}

1. Meetings to express protest against the activities of GKChP and support for Yeltsin.

2. Ordinary strikes supporting the government of the Russian Republic as an expressed refusal of economic cooperation. 


\section{Rejecting the „Soviet government” and refusing to cooperate with it as} well as actions taken by representatives of various state structures - in response to the declaration of the Soviet government Boris Yeltsin issued the „Appeal to the Citizens of Russia”, in which GKChP was recognized as an unconstitutional body. All normative acts issued by the putsch members were considered to be against the law and the supremacy of the constitution and RSFSR law was stressed. The „Appeal” also included a call to Russian citizens for civil disobedience in the form of e.g. general indefinite strike, and to soldiers for showing the sense of social responsibility and not taking part in the reactionary coup (Boriew, 1992, pp. 28-29). Next, the decree issued on 19 August 1991described the activities of $\mathrm{GKChP}$ as a crime against the state, which forced the members of the nomenklatura to take a stand on one of the sides: either with the „Soviet government” or with the defenders of democracy. Invoking the national interest allowed the leader of the Russian Republic to gain control over the USSR executive bodies on the RSFSR territory, including the KGB, the Ministry of Internal Affairs and the armed forces. All the members of the August coup were considered as outlaws and were to be brought to justice ${ }^{9}$. In the last decree issued on that day, president Yeltsin reminded the prosecution authorities, the state security service and the army about the necessity of acting in compliance with the constitution of the USSR and the RSFSR. As a result, the following forms of civil disobedience regarding the refusal to cooperate with the "Soviet government” can be identified in the activities of Muscovites and the state structures:

1. Disloyalty to authorities - the so-called „Soviet government”, and full solidarity with the interned president of the USSR and with the authorities of the Russian Republic.

2. Refusal to give support.

3. Leaflets and speeches calling for resistance.

9 From the perspective of the events which happened two years later, in October 1993, Yeltsin received in August ' 91 social support also because he did not threaten the putsch members with death penalty. At that time in the USSR there was a moratorium on its use, and formulating such a threat was treated then as a danger of coming back to mass repression - a memory of which was still vivid. In October 1993 during the self-coup launched de facto by the incumbent president Boris Yeltsin, who illegally dissolved the Russian parliament and introduced the presidential government until the elections of a new Russian parliament, the so called „defenders of parliamentary system” (Chairman of the Presidium of the Supreme Soviet Ruslan Khasbulatov and vice president Alexander Rutskoy) who were the leaders of the parliamentary opposition, threatened to impound the property of the president, of his supporters, and of the members of the Russian government led by Viktor Chernomyrdin. Moreover, the opposition threatened the presidential camp with death penalty.To read more, see: Jach, 2011, p. 308. 
4. Boycott of the Supreme Soviet of the Soviet Union.

5 . Boycott of the government ministries, bodies and government branches.

6. Refusal to accept appointed officials.

7. Disagreement with dissolving and suspending existing organisations.

8. Refusal presented by close government collaborators - the nomenklatura, who were forced to make a choice between the GKChP and Yeltsin/Gorbachev.

9. Blocking the flow of instructions and information by the units.

10. Delays and obstructing the activities of units controlled by the GKChP.

11. General refusal of cooperation from the side of the union and republican administration.

12. Lack of cooperation from the side of the judiciary.

13. Intentional ineptitude and partial refusal to cooperate displayed by the USSR armed forces and police services - one of the key issues was evasion and refusal to follow orders given by the members of the GKChP, mainly issued by General Kryuchkov and Marshal Yazov. To illustrate those kinds of actions, it is necessary to recall the behaviour of the commander of „Alpha” who as early as on 19 August 1991 refused to initiate the procedure of interning, Yeltsin and the members of the government of the Russian Republic, which consequently allowed them to come to Moscow (Jach, 2011, p. 66).

To conclude, it should be stated that whatever form the political regime may take, the decision to engage in activities which display civil disobedience always leads to the development of new forms of social conduct. The difficulty is, however, how to use the atmosphere created during social mobilization. This was the case of the August coup. The public feeling present at that moment was not used for building new standards in functioning of the system since both the putsch members and the defenders of the White House represented the old, communist style of governing. They were not interested in fundamental transformation of the system as this would have resulted in removing the government members who would have lost their lucrative posts in the state administration (owing to the necessity of holding new elections), all the privileges, and their position in the social structure. Therefore, a new constitution based on democratic standards was not enacted, and no process of changing the government was initiated. In practice, the situation generated increased tension within individual branches of the authorities due 
to the lack of division of competences, and also made the citizens gradually lose their interest in socio-political life and focus on ensuring safety of their families, friends and their own.

\section{References:}

Arendt, H. (1998). O przemocy. Nieposłuszeństwo obywatelskie. Warszawa: Fundacja Aletheia.

Boriew, W. (1992). 3 dni. Warszawa: Wydawnictwo Amber.

Dobbs, M. (1998). Precz z Wielkim Bratem. Upadek imperium radzieckiego. Poznań: Dom Wydawniczy Rebis.

Drabinek, A. (1998). Sensacje XX wieku - Pucz Janajewa. A documentary film. Poland: Telewizja Polska.

Hergren, P. (1997). Podstawy obywatelskiego nieposłuszeństwa, (BZB 20). Kraków: Wydawnictwo Zielone Brygady.

Jach, A. (2011). Rosja 1991-1993. Walka o nowy kształt ustrojowy państwa. Kraków: Wydawnictwo Księgarnia Akademicka.

Niekrasow, A. (2011). Żegnajcie, towarzysze. Część 6 Upadek 1990-1991. A documentary film. Germany, Finland, France.

Pichoja, R.G. (2011). Historia władzy w Zwiazku Radzieckim 1945-1991. Warszawa: Wydawnictwo Uniwersytetu Jagiellońskiego.

Rawls, J. (1994). Teoria sprawiedliwości. Warszawa: PWN.

Sharp, G. (2013). Appendix One. Formy pokojowego oporu. Od dyktatury do demokracji. Drogi do wolności. Warszawa: Fundacja Wolność i Pokój.

Thom, F. (1990). Czas Gorbaczowa. Warszawa: Wydawnictwo Delikon.

Thoreau, H.D. (1997). Nieposłuszeństwo obywatelskie. Zielona Góra: PWN.

Государственный комитет по чрезвычайному положению в СССР „Заявление Советского Руководства”. Retrieved from: http://souz.info/library/other/gkchp/ gkchpzaiav.htm.

Государственный комитет по чрезвычайному положению в СССР „Обращение к Советскому Народу”. Retrieved from: http://souz.info/library/other/gkchp/gkchpobr. htm.

Кречетников, А. Хроника путча: часть I - V, 17-22 VIII 2006, Retrieved from: http:// news.bbc.co.uk/hi/russian/russia/newsid_4800000/4800701.stm - http://news.bbc. co.uk/hi/russian/russia/newsid_5273000/5273360.stm.

Манифестация у здания Верховного Совета РСФСР, Retrieved from: http://visualrian. $\mathrm{ru} / \mathrm{ru} /$ site/gallery/\#471251.

Обухов, С.П.(2005). Российский парламентаризм между признанием а отторжением. Проблема массого восприяния (1985-2005 гг.). Москва: ИПЦ «Маска».

Пинскер, Д. Свободное радио. Остальное - видимость, „Итоги” №34 / 220 (21.08.00). Retrieved from: http://www.itogi.ru/archive/2000/34/115109.html.

Путч. Хроника тревожних дней - Москва 1991. (1991b). Retrieved from: http://old. russ.ru/antolog/1991/f05.jpg. 
Путч. Хроника тревожних дней - Москва 1991. (1991a). Retrieved from: http://old. russ.ru/antolog/1991/index.html.

Радио «Эхо Москвы», Интервью: Мстислав Ростропович и Алексей Венедиктов, 23 августа 1991, Retrieved from: http://echo.msk.ru/programs/beseda/51365/.

Собчак, А.А. (1999). Из Ленинграда в Петербург: Путешествие во времени и пространстве. Санкт-Петербнрг: Издательство «Контрфорс».Lanham.pdf.A paper presented in the 2nd International Conference on Humanities and Social Sciences on April 10th, 2010 in Faculty of Liberal Arts, Prince of Songkla University Strategies Teaching.

Suyanto, A. (2010). The Effectiveness of Mindmapping to Teach Writing Skill Viewed from Their IQ (An Experimental Study on the Seventh Grade Students of SMPN 1 Prambon in the Academic Year 2009/2010). Thesis. Surakarta. English Education Department of Graduate School, Sebelas Maret University of Surakarta, 2010. 